
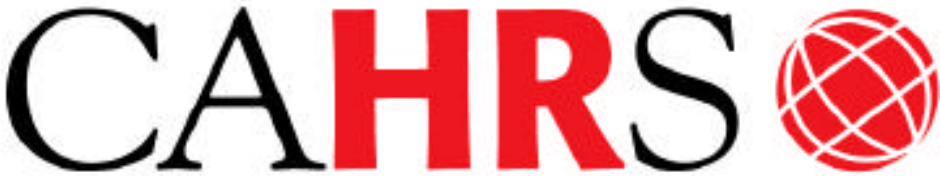

Center for Advanced Human Resource Studies

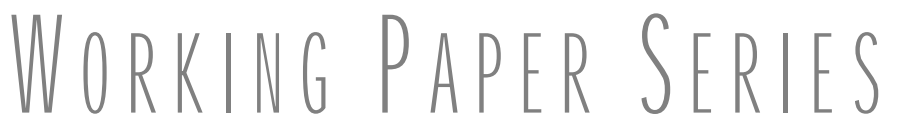

CAHRS / Cornell University 187 Ives Hall

Ithaca, NY 14853-3901 USA Tel. 607 255-9358

www.ilr.cornell.edu/CAHRS/

\title{
Human Resources and the Resource Based View of the Firm
}

Benjamin B. Dunford

Scott A. Snell

Patrick M. Wright

Working Paper $01-03$ 


\title{
Human Resources and the Resource Based View of the Firm
}

\author{
Benjamin B. Dunford \\ Department of Human Resource Studies \\ School of Industrial and Labor Relations \\ Cornell University \\ Ithaca, NY 14853-3901 \\ Scott A. Snell \\ Department of Human Resource Studies \\ School of Industrial and Labor Relations \\ Cornell University \\ Ithaca, NY 14853-3901 \\ Patrick M. Wright \\ Department of Human Resource Studies \\ School of Industrial and Labor Relations \\ Cornell University \\ Ithaca, NY 14853-3901
}

October 5, 2001

http://www.ilr.cornell.edu/cahrs

This paper has not undergone formal review or approval of the faculty of the ILR School. It is intended to make results of Center research available to others interested in preliminary form to encourage discussion and suggestions. 


\begin{abstract}
The resource-based view (RBV) of the firm has influenced the field of strategic human resource management (SHRM) in a number of ways. This paper explores the impact of the RBV on the theoretical and empirical development of SHRM. It explores how the fields of strategy and SHRM are beginning to converge around a number of issues, and proposes a number of implications of this convergence.
\end{abstract}




\section{Human Resources and the Resource Based View of the Firm}

The human resource function has consistently faced a battle in justifying its position in organizations (Drucker, 1954; Stewart, 1996). In times of plenty, firms easily justify expenditures on training, staffing, reward, and employee involvement systems, but when faced with financial difficulties, such HR systems fall prey to the earliest cutbacks.

The advent of the sub field of strategic human resource management (SHRM), devoted to exploring HR's role in supporting business strategy, provided one avenue for demonstrating its value to the firm. Walker's (1978) call for a link between strategic planning and human resource planning signified the conception of the field of SHRM, but its birth came in the early 1980's with Devanna, Fombrum, \& Tichy's (1984) article devoted to extensively exploring the link between business strategy and HR. Since then, SHRM's evolution has consistently followed (by a few years) developments within the field of strategic management. For example, Miles and Snow's (1978) organizational types were later expanded to include their associated HR systems (Miles and Snow, 1984). Porter's (1980) model of generic strategies was later used by SHRM researchers to delineate the specific HR strategies one would expect to observe under each of them (Jackson, \& Schuler, 1987; Wright and Snell, 1991).

Though the field of SHRM was not directly born of the RBV, it has clearly been instrumental to its development. This was largely due to the RBV shifting emphasis in the strategy literature away from external factors (such as industry position) toward internal firm resources as sources of competitive advantage (Hoskisson, Hitt, Wan, \& Yiu, 1999). Growing acceptance of internal resources as sources of competitive advantage brought legitimacy to HR's assertion that people are strategically important to firm success. Thus, given both the need to conceptually justify the value of HR and the propensity for the SHRM field to borrow concepts and theories from the broader strategy literature, the integration of the resource-based view of the firm (RBV) into the SHRM literature should surprise no one. 
However, two developments not as easily predicted have emerged over the past 10 years. First, the popularity of the RBV within the SHRM literature as a foundation for both theoretical and empirical examinations has probably far surpassed what anyone expected (McMahan, Virick, \& Wright, 1999). Second, the applications and implications of the RBV within the strategy literature have led to an increasing convergence between the fields of strategic management and SHRM (Snell, Shadur, \& Wright, in press). Within the strategic literature, the RBV has helped to put "people" (or a firm's human resources) on the radar screen. Concepts such as knowledge (Argote, \& Ingram, 2000; Grant, 1996, Leibeskind, 1996), dynamic capability (Eisenhardt \& Martin, 2000; Teece, Pisano, \& Schuen, 1997), learning organizations (Fiol \& Lyles, 1985; Fisher \& White, 2000), and leadership (Finkelstein \& Hambrick, 1996; Norburn \& Birley, 1988; Thomas, 1988) as sources of competitive advantage turn attention toward the intersection of strategy and HR issues.

The purpose of this paper is to examine how the RBV has been applied to the theoretical and empirical research base of SHRM, and to explore how it has provided an accessible bridge between the fields of strategy and HR. In order to accomplish this, we will first review the specific benchmark articles that have applied the RBV to theoretical development of SHRM. We will then discuss some of the empirical SHRM studies that have used the RBV as the basis for exploring the relationship between HR and firm performance. Finally, we will identify some of the major topic areas that illustrate the convergence of the fields of strategy and $\mathrm{HR}$, and propose some future directions for how such a convergence can provide mutual benefits.

\section{Applying the Resource-based View to SHRM}

While based in the work of Penrose (1959) and others, Wernerfelt's (1984) articulation of the resource based view of the firm certainly signified the first coherent statement of the theory. This initial statement of the theory served as the foundation that was extended by others such as Rumelt (1984), Barney (1996), and Dierickx and Cool (1989). However, Barney's (1991) specification of the characteristics necessary for a sustainable competitive advantage seemed 
to be a seminal article in popularizing the theory within the strategy and other literatures. In this article he noted the resources which are rare, valuable, inimitable, and non-substitutable can provide sources of sustainable competitive advantages.

Although debates about the RBV continue to wage (e.g., whether the RBV is a theory, whether it is tautological, etc. Priem \& Butler, 2001a, 2001b, Barney, 2001) even its critics have acknowledged the "breadth of its diffusion" in numerous strategic research programs (Priem \& Butler, 2001a:25-26). With its emphasis on internal firm resources as sources of competitive advantage, the popularity of the RBV in the SHRM literature has been no exception. Since Barney's (1991) article outlining the basic theoretical model and criteria for sources of sustainable competitive advantage, the RBV has become by far, the theory most often used within SHRM, both in the development of theory and the rationale for empirical research (McMahan, Virick, \& Wright, 1999).

\section{Resource-based View and SHRM Theory}

As part of Journal of Management's Yearly Review of Management issue, Wright and McMahan (1992) reviewed the theoretical perspectives that had been applied to SHRM. They presented the RBV as one perspective that provided a rationale for how a firm's human resources could provide a potential source of sustainable competitive advantage. This was based largely on what was, at the time a working paper, but later became the Wright, McMahan, and McWilliams (1994) paper described later.

Almost simultaneously, Cappelli and Singh (1992), within the industrial relations literature, provided an examination of the implications of the RBV on SHRM. Specifically, they noted that most models of SHRM based on fit assume that (a) a certain business strategy demands a unique set of behaviors and attitudes from employees and (b) certain human resource policies produce a unique set of responses from employees. They further argued that many within strategy have implicitly assumed that it is easier to rearrange complementary assets/resources given a choice of strategy than it is to rearrange strategy given a set of 
assets/resources, even though empirical research seems to imply the opposite. Thus, they proposed that the resource-based view might provide a theoretical rationale for why HR could have implications for strategy formulation as well as implementation.

Shortly thereafter, two articles came out arguing almost completely opposite implications of the potential for HR practices to constitute a source of sustainable competitive advantage. Wright et al. (1994), mentioned above, distinguished between the firm's human resources (i.e., the human capital pool) and HR practices (those HR tools used to manage the human capital pool). In applying the concepts of value, rareness, inimitability, and substitutability, they argued the HR practices could not form the basis for sustainable competitive advantage since any individual HR practice could be easily copied by competitors. Rather, they proposed that the human capital pool (a highly skilled and highly motivated workforce) had greater potential to constitute a source of sustainable competitive advantage. These authors noted that in order to constitute a source of competitive advantage, the human capital pool must have both high levels of skill and a willingness (i.e., motivation) to exhibit productive behavior. This skill/behavior distinction appears as a rather consistent theme within this literature.

In contrast, Lado and Wilson (1994) proposed that a firm's HR practices could provide a source of sustainable competitive advantage. Coming from the perspective of exploring the role of HR in influencing the competencies of the firm, they suggested that HR systems (as opposed to individual practices) can be unique, causally ambiguous and synergistic in how they enhance firm competencies, and thus could be inimitable. Thus, whereas Wright et al. (1994) argued for imitability of individual practices, Lado and Wilson noted that the system of HR practices, with all the complementarities and interdependencies among the set of practices, would be impossible to imitate. This point of view seems well accepted within the current SHRM paradigm (Snell, Youndt, \& Wright, 1996).

Boxall (1996) further built upon the RBV/SHRM paradigm, suggesting that human resource advantage (i.e., the superiority of one firm's HRM over another) consists of two parts. 
First, human capital advantage refers to the potential to capture a stock of exceptional human talent "latent with productive possibilities." (p. 67). Human process advantage can be understood as a "function of causally ambiguous, socially complex, historically evolved processes such as learning, cooperation, and innovation." (p. 67). Boxall (1998) then expanded upon this basic model presenting a more comprehensive model of strategic HRM. He argued that one major task of organizations is the management of mutuality (i.e., alignment of interests) in order to create a talented and committed workforce. It is the successful accomplishment of this task that results in a human capital advantage. A second task is to develop employees and teams in such a way as to create an organization capable of learning within and across industry cycles. Successful accomplishment of this task results in the organizational process advantage. Most recently, Lepak and Snell (1999) presented an architectural approach to SHRM based at least partly in the RBV. They proposed that within organizations, considerable variance exists with regard to both the uniqueness and value of skills. Juxtaposing these two dimensions, they built a $2 \times 2$ matrix describing different combinations with their corresponding employment relationships and HR systems. The major implication of that model was that some employee groups are more instrumental to competitive advantage than others. As a consequence, they are likely to be managed differently. While the premise of an architectural perspective is rooted in extant research in HR (cf., Baron, et al., 1986; Osterman, 1987; Tsui Pearce, Porter, \& Tripoli, 1997) and strategy (cf., Matusik \& Hill, 1998), Lepak and Snell (1999) helped SHRM researchers recognize that real and valid variance exists in HR practices within the organization, and looking for one HR strategy may mask important differences in the types of human capital available to firms. (cf., Truss \& Gratton, 1994).

In essence, the conceptual development within the field of SHRM has leveraged the RBV to achieve some consensus on the areas within the human resource architecture in which sustainable competitive advantage might be achieved. Figure 1 depicts these components. 


\section{Figure 1}

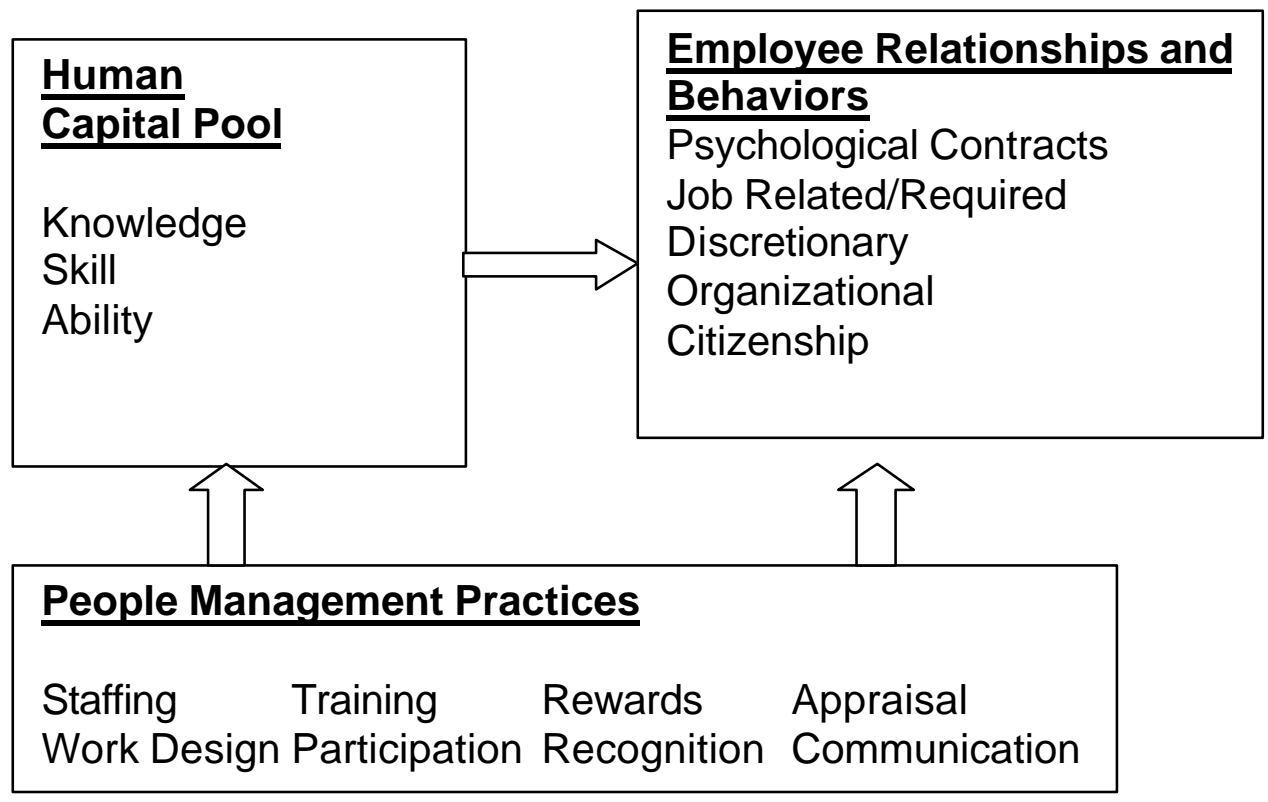

First, the human capital pool refers to the stock of employee skills that exist within a firm at any given point in time. Theorists focus on the need to develop a pool of human capital that has either higher levels of skills (general and/or firm specific), or achieving a better alignment between the skills represented in the firm and those required by its strategic intent. The actual stock of human capital can and does change overtime, and must constantly be monitored for its match with the strategic needs of the firm.

Second, an increasing consensus is emerging among researchers that employee behavior is an important independent component of SHRM. Distinct from skills of the human capital pool, employee behavior recognizes individuals as cognitive and emotional beings who possess free will. This free will enables them to make decisions regarding the behaviors in which they will engage. This is an important, if subtle, distinction. A basic premise of human capital theory is that firms do not own it; individuals do. Firms may have access to valuable 
human capital, but either through the poor design of work or the mismanagement of people, may not adequately deploy it to achieve strategic impact. For example, MacDuffie (1995) focuses on the concept of discretionary behavior. Discretionary behavior recognizes that even within prescribed organizational roles, employees exhibit discretion that may have either positive or negative consequences to the firm. Thus, a machine operator who hears a "pinging" has discretion to simply run the machine until something breaks or to fix the problem immediately, and thus save significant downtime. Similar to March and Simon's (1958) concept of "the decision to contribute" SHRM's focus on discretionary behavior recognizes that competitive advantage can only be achieved if the members of the human capital pool individually and collectively choose to engage in behavior that benefits the firm.

Finally, while many authors describe HR practice or High Performance Work Systems, a broader conceptualization might simply be the people management systems. By using the term system, we turn focus to the importance of understanding the multiple practices that impact employees (Wright \& Boswell, in press) rather than single practices. By using the term people, rather than $\mathrm{HR}$, we expand the relevant practices to those beyond the control of the $\mathrm{HR}$ function, such as communication (both upward and downward), work design, culture, leadership, and a host of others that impact employees and shape their competencies, cognitions, and attitudes. Effective systems for managing people evolve through unique historical paths and maintain interdependence among the components that competitors cannot easily imitate (Becker \& Huselid, 1998). The important aspect of these systems is that they are the means through which the firm continues to generate advantage over time as the actual employees flow in and out and the required behaviors change due to changing environmental and strategic contingencies. It is through the people management systems that the firm influences the human capital pool and elicits the desired employee behavior. This dynamic process, while not depicted in the figure, will be taken up later in the paper. 
The implications of our figure and this model are that while a firm might achieve a superior position in any one of the three, sustainable competitive advantage requires superior positions on all three.

This is due to three reasons. First, the value that skills and behaviors can generate requires that they be paired together (i.e., without skills, certain behaviors cannot be exhibited, and that the value of skills can only be realized through exhibited behavior.) Second, it is difficult to conceive of a firm's human capital pool containing both the highest levels of skills and exhibiting optimal behaviors in the absence of an aligned people management system. Finally, the effects of the people management systems are subject to time compression diseconomies (Dierickx \& Cool, 1989). While these systems might be immediately imitated, a significant time lag will occur before their impact is realized, thus making it costly or difficult for competitors to imitate the value generated by the human capital pool. We will later build upon this model to explore how this fits within the larger organization.

Summary of RBV based conceptual literature. In summary, the RBV has proven to be integral to the conceptual and theoretical development of the SHRM literature. Our brief review demonstrates how the RBV based SHRM research has evolved in the last decade. This evolution began when HR researchers recognized that the RBV provided a compelling explanation for why HR practices lead to competitive advantage. Ensuing scholarly debate about the specific mechanics of this relationship advanced the SHRM literature to its current state. The net effect has been a deeper understanding of the interplay between HRM and competitive advantage. The model depicted in figure 1 demonstrates that sustained competitive advantage is not just a function of single or isolated components, but rather a combination of human capital elements such as the development of stocks of skills, strategically relevant behaviors, and supporting people management systems. Although there is yet much room for progress it is fair to say that the theoretical application of the RBV has been successful in 
stimulating substantial amount of activity in the SHRM arena. Having summarized the conceptual development, we now turn to the empirical research.

\section{Resource-based View and Empirical SHRM Research}

In addition to the many applications of the RBV to the theoretical developments within SHRM, this perspective also has emerged as one of the more popular foundations for exploring empirical relationships within SHRM. In fact, one is hard pressed to find any SHRM empirical studies conducted over the past few years that do not at least pay lip service to the RBV. In the interest of brevity, we will cover a sample of such studies that illustrate the application of RBV concepts to empirical SHRM research. We chose these studies either because they specifically attempt to build on resource-based theory or because tend to be most frequently cited within the SHRM literature and at least tangentially rely on resource-based logic.

In an early application, Huselid (1995) argued at a general level that HR practices could help create a source of competitive advantage, particularly if they are aligned with the firm's competitive strategy. His study revealed a relationship between HR practices (or High Performance Work Systems) and employee turnover, gross rate of return on assets, and Tobin's $Q$. That study received considerable attention because it demonstrated that HR practices could have a profound impact on both accounting and market based measures of performance.

Koch and McGrath (1996) took a similar logic in their study of the relationship between HR planning, recruitment, and staffing practices and labor productivity. They argued that "...a highly productive workforce is likely to have attributes that make it a particularly valuable strategic asset," (p. 335). They suggested firms that develop effective routines for acquiring human assets develop a stock of talent that cannot be easily imitated. They found that these HR practices were related to labor productivity in a sample of business units, and that this relationship was stronger in capital-intensive organizations. 
Boxall and Steeneveld (1999) conducted a longitudinal case study of participants in the New Zealand engineering consultancy industry. They suggested that one of the firms in the industry had achieved a superior competitive position due to its human resource advantage in 1994, but that by 1997 two of the competitors had caught up in the competitive marketplace. They posited that this could mean that either the two competitors had been able to successfully imitate the former leaders' human resource advantage, or that the former leader has developed an advantage about which there is presently uncertainty, but which will be exploited in the future.

Diverging from the focus on HR practices, Wright, McMahan \& Smart (1995) studied NCAA Men's basketball teams using an RBV framework. They focused on the skills of the team members and experience of the coach, and examined how a fit between skills and strategy impacted the team's performance. They found that the relationship between certain skills and team performance depended upon the strategy in which the team was engaged. In addition, their results indicated that teams whose coaches who were using a strategy different from their preferred strategy performed lower than teams where the coach was able to use his preferred strategy.

Recent empirical studies using the RBV build on Lepak and Snell's (1999) architectural framework discussed above. Lepak and Snell (in press) asked executives to describe the HR systems that existed for jobs that represented particular quadrants of their model. The found considerable support for the idea that the value and uniqueness of skills are associated with different types of HR systems within the same organization. These results were mostly consistent with the Lepak and Snell (1999) model, and supported the basic proposition that diverse HR strategies exist within firms. A follow up study (Lepak, Takeuchi, \& Snell, 2001) indicated that a combination of knowledge work and contract labor was associated with higher firm performance. This finding not only raises some interesting ideas about the development of 
valuable human resources, but also highlights the importance of combinations of various types used in conjunction with one another.

In another example of examining the human capital pool, Richard (2001) used resourcebased logic to examine the impact of racial diversity on firm performance. He argued that diversity provides value through ensuring a variety of perspectives, that it is rare in that very few firms have achieved significant levels of diversity, and that the socially complex dynamics inherent in diversity lead to its inimitability. He found in a sample of banks that diversity was positively related to productivity, return on equity, and market performance for firms engaged in a growth strategy, but negatively related for firms downsizing.

In an effort to look beyond human capital pool alone, Youndt and Snell (2001) studied the differential effects of HR practices on human capital, social capital, and organizational capital. They found that intensive/extensive staffing, competitive pay, intensive/extensive training and promotion from within policies were most important for distinguishing high levels of human capital in organizations. In contrast, broad banding, compressed wages, team structures, socialization, mentoring, and group incentives distinguished those with high social capital (i.e., relationships that engender knowledge exchange) but had very little effect on human capital itself. Finally, organizational capital (i.e., knowledge embedded in the organization's systems and processes) was established most through lessons learned databases and HR policies that reinforced knowledge capture and access.

Summary of RBV based Empirical Research: Limitations and Future directions. Recent debate about the usefulness of the RBV provides an interesting commentary about the current state of SHRM research (Barney, 2001; Priem \& Butler, 2001a). In response to claims that the RBV is tautological and does not generate testable hypotheses, Barney recognizes that most research applying the RBV has failed to test its fundamental concepts. Rather, he notes that much of the existing research has used the RBV to "establish the context of some empirical research—for example that the focus is on the performance implications of some internal 
attribute of a firm—and are not really direct tests of the theory developed in the 1991 article." (Barney, 2001: 46, emphasis added).

The underlying logic of much of the existing SHRM research falls into this category. Although the empirical application of the RBV has taken a variety of forms, ranging in focus from High Performance Work Systems and stocks of talent, to the fit between employee skills and strategy it has employed a common underlying logic: Human resource activities are thought to lead to the development of a skilled workforce and one that engages in functional behavior for the firm, thus forming a source of competitive advantage. This results in higher operating performance, which translates into increased profitability, and consequently results in higher stock prices (or market values) (Becker \& Huselid, 1998). While this theoretical story is appealing, it is important to note that ultimately, most of the empirical studies assess only two variables: HR practices and performance.

While establishing such a relationship provides empirical evidence for the potential value of HR to firms, it fails to adequately test the RBV in two important ways. First, no attempt has yet been made to empirically assess the validity of the proposition that HR practices (or HPWS) are path dependent or causally ambiguous, nor whether they are actually difficult to imitate. While intuitively obvious and possibly supported by anecdotal data, the field lacks verifiable quantitative data to support these assertions. In fact, Boxall and Steeneveld's (1999) findings might suggest that HR systems are more easily imitated (or at least substitutable) than SHRM researchers previously believed. Certainly, efforts such as King and Zeithaml's (2001) study assessing causal ambiguity of competencies could be replicated with regard to SHRM issues. These authors asked managers to evaluate their firms competencies and the generated measures of causal ambiguity based on these responses. While ambiguity was negatively related to firm performance in their study, they provide an example of how one might attempt to measure some of the variables within the resource based view. 
Second, few attempts have been made to demonstrate that the HR practices actually impact the skills or behaviors of the workforce, nor that these skills or behaviors are related to any performance measures. Arthur (1994) and Huselid (1995) did find a relationship between HR practices and turnover. Wright, McCormick, Sherman and McMahan (1999) found that appraisal and training practices were related to executives' assessment of the skills and that compensation practices were related to their assessments of workforce motivation. However, as yet no study has demonstrated anything close to a full causal model through which HR practices are purported to impact firm performance.

In short, a major step forward for the SHRM literature will be to move beyond simply the application of RBV logic to HR issues toward research that directly tests the RBV's core concepts. In fairness, this state of affairs does not differ from attempts to study competitive advantage within the strategy literature. As noted by Godfrey and Hill (1995), it is impossible to assess the degree of unobservability of an unobservable, and inimitable resources are often purported to be unobservable. Thus, strategy researchers are often left to using proxy variables that may not be valid for measuring the underlying constructs (Hoskisson, Hitt, Wan, \& Yiu, 1999).

However, given the single respondent, cross sectional, survey designs inherent in much of this research, one cannot rule out alternative explanations for the findings of empirical relationships. For example, Gerhart, Wright, McMahan, and Snell (2000) and Wright, Gardner, Moynihan, Park, Gerhart and Delery (in press) both found that single respondent measures of HR practices may contain significant amounts of measurement error. Gardner, Wright, and Gerhart (2000) also found evidence of implicit performance theories suggesting that respondents to HR surveys might base their descriptions of the HR practices on their assessments of the organization's performance. This raises the possibility that research purporting to support the RBV through demonstrating a relationship between HR and performance may result from spurious relationships, or even reverse causation (Wright and 
Gardner, in press). The point is not to discount the significant research that has been conducted to date, but rather to highlight the importance of more rigorous and longitudinal studies of HR from a RBV perspective.

Taking a deeper understanding the resource-based view of the firm into empirical SHRM research entails focusing primarily on the competencies and capabilities of firms and the role that people management systems play in developing these. It requires recognizing that the inimitability of these competencies may stem from unobservability (e.g., causal ambiguity), complexity (e.g., social complexity), and/or time compression diseconomies (e.g., path dependence). This implies that rather than simply positing a relationship between HR practices and sustainable competitive advantage, one must realize that people management systems might impact this advantage in a variety of ways.

For instance, these systems might play a role in creating cultures or mindsets that enable the maintenance of unique competencies (e.g., the safety record of DuPont). Or, these systems may promote and maintain socially complex relationships characterized by trust, knowledge sharing, and teamwork (e.g., Southwest Airlines' unique culture). Finally, these systems might have resulted in the creation of a high quality human capital pool that cannot be easily imitated because of time compression diseconomies (e.g., Merck's R\&D capability). Whichever the case, it certainly calls for a more complex view of the relationship between HR and performance than is usually demonstrated within the empirical literature.

In addition to a more complex view, such grounding would imply different strategies for studying HR and competitive advantage. For instance, recognizing time compression diseconomies implies more longitudinal or at least historical approaches to examining competitive advantage as opposed to the more popular cross-sectional studies. Focusing on causal ambiguity and social complexity might suggest more qualitative approaches than simply asking subjects to report via survey about the HR practices that exist. In sum, strategic HRM research more strongly anchored in the resource based view of the firm would look significantly 
different than what currently exists. However, such research would shed light on both HR and strategy issues.

Extending this further, strategists who embrace the RBV point out that competitive advantage (vis core competence) comes from aligning skills, motives, etc. with organizational systems, structures, and processes that achieve capabilities at the organizational level (Hamel \& Prahalad, 1994; Peteraf, 1993; Teece, Pisano and Shuen, 1997). Too frequently, HR researchers have acted as if organizational performance derives solely from the (aggregated) actions of individuals. But the RVB suggests that strategic resources are more complex than that, and more interesting. Companies that are good at product development and innovation, for example, don't simply have the most creative people who continually generate new ideas. Product development capabilities are imbedded in the organizational systems and processes. People execute those systems, but they are not independent from them. So while core competencies are knowledge-based, they are not solely human. They are comprised of human capital, social capital (i.e., internal/external relationships and exchanges), and organizational capital (i.e., processes, technologies, databases) (Snell, Youndt, \& Wright, 1996).

That doesn't negate the importance of HR; it amplifies it and extends it. The RVB provides a broader foundation for exploring the impact of HR on strategic resources. In this context, HR is not limited to its direct effects on employee skills and behavior. Its effects are more encompassing in that they help weave those skills and behaviors within the broader fabric of organizational processes, systems and, ultimately, competencies.

Notwithstanding a great deal of room for development, it is clear from the preceding review that the conceptual and empirical application of the RBV has led to considerable advancement of the SHRM literature. In a broader sense, the RBV has impacted the field of HRM in two important ways. First, the RBV's influence has been instrumental in establishing a macro perspective in the field of HRM research (Snell et al, in press). This macro view has provided complimentary depth to a historically micro discipline rooted in psychology. Relatedly, 
a second major contribution of the RBV has been the theoretical and contextual grounding that it has provided to a field that has often been criticized for being atheoretical and excessively applied in nature (Snell, et al., In press).

\section{The Convergence of RBV and SHRM: Potential Mutual Contributions}

Thus far we have discussed how the RBV has contributed to the field of SHRM. As noted before, however, that the RBV has also effectively put "people" on the strategy radar screen (Snell et al., in press). In the search for competitive advantage, strategy researchers increasingly acknowledge human capital (Hitt, Bierman, Shimizu, \& Kochar, 2001), intellectual capital (Edvinsson \& Malone, 1997) and knowledge (Grant, 1996; Leibeskind, 1996; Matusik \& Hill, 1998) as critical components. In so doing, the RBV has provided an excellent platform for highlighting the importance of people to competitive advantage, and thus, the inescapable fact that RBV strategy researchers must bump up against people and/or HR issues.

In fact, recent developments within the field of strategy seem to evidence a converging of that field and SHRM (Snell et al., in press). It seems that these areas present unique opportunities for interdisciplinary research streams that provide significant leaps forward in the knowledge base. We will discuss the concept of core competencies, the focus on dynamic capabilities, and knowledge-based views of the firm as potential bridges between the HR and strategy literatures. We choose these concepts because of both their popularity within the strategy literature and their heavy reliance on HR related issues.

\section{Core Competencies}

Prahalad and Hamel (1990) certainly popularized the core competency concept within the strategy literature. They stated that core competencies are "...the collective learning in the organization, especially how to coordinate diverse production skills and integrate multiple streams of technologies," (p. 64), and that they involve "many levels of people and all functions," (p. 64). While the distinctions between core competencies and capabilities (Stalk, Evans, \& 
Schulman, 1992) seems blurred, one can hardly conceptualize a firm capability or competency absent the people who comprise them nor the systems that maintain them.

For example, competencies or capabilities refer to organizational processes, engaged in by people, resulting in superior products, and generally these must endure over time as employees flow in, through and out of the firm. Numerous researchers within the strategy field focus on firm competencies (e.g, King \& Zeithaml, 2001, Leonard-Barton, 1992; 1995). These researchers universally recognize the inseparability of the competence and the skills of the employees who comprise the competence. In addition, some (e.g., Leonard-Barton, 1992) specifically also recognize the behavioral aspect of these employees (i.e., their need to engage in behaviors that execute the competency) and the supportive nature of people management systems to the development/maintenance of the competency. However, often these treatments begin quite specifically when examining the competency and its competitive potential within the marketplace. However, they then sometimes become more generic and ambiguous as they delve into the more specific people-related concepts such as knowledges, skills, abilities, behaviors, and HR practices.

This illustrates the potential synergy that might result from deeper integration of the strategy and strategic HRM literatures. To deeply understand the competency one must examine (in addition to the systems and processes that underlie them) the people who engage in the process, the skills they individually and collectively must possess, and the behavior they must engage in (individually and interactively) to implement the process. In addition, to understand how such a competency can be developed or maintained requires at least in part examining the people management systems that ensure that the competency remains as specific employees leave and new employees must be brought in to replace them. This again exemplifies the interaction of people and processes as they comprise competencies.

Focusing on the people-related elements of a core competency provides a linking pin between the strategy and HR literatures. Traditional HR researchers refer to a "competence" as 
being a work related knowledge, skill, or ability (Nordhaug, 1993) held by an individual. This is not the same as the core competencies to which strategy researchers refer. Nordhaug and Gronhaug (1994) argue that firms possess individuals with different competences that they refer to as a portfolio of competences. They further propose that a core (or distinctive) competence exists when a firm is able to collaboratively blend the many competences in the portfolio, through a shared mindset, in order to better perform something than their competitors. For SHRM researchers, this implies a need to develop an understanding of firms, the activities in their value chains, and the relative superiority in value creation for each of these activities. For strategy researchers, it suggests a need to more deeply delve into the issues of the individuals and groups who comprise the competency, and the systems that develop and engage them to exhibit and maintain the competency. Lepak and Snell's (1999) model provides one tool for making this link between the firm's competency, the people that comprise it, and the systems that maintain it.

\section{Dynamic Capabilities.}

The RBV has frequently focused on resources or competencies as a stable concept that can be identified at a point in time and will endure over time. The argument goes that when firms have bundles of resources that are valuable, rare, inimitable and non-substitutable, they can implement value creating strategies not easily duplicated by competing firms (Barney, 1991; Conner \& Prahalad, 1996; Peteraf, 1993; Wernerfelt, 1984, 1995).

However, recent attention has focused on the need for many organizations to constantly develop new capabilities or competencies in a dynamic environment (Teece, Pisano, and Schuen, 1997). Such capabilities have been referred to as "dynamic capabilities" which have been defined as:

The firm's processes that use resources - specifically the processes to integrate, reconfigure, gain, and release resources - to match and even create market change. Dynamic capabilities thus are the organizational and strategic routines 
by which firms achieve new resource reconfigurations as markets emerge, collide, split, evolve, and die. (Eisenhardt \& Martin, 2000)

Such dynamic capabilities require that organizations establish processes that enable them to change their routines, services, products, and even markets over time. While in theory, one can easily posit how organizations must adapt to changing environmental contingencies, in reality changes of this magnitude are quite difficult to achieve, and the difficulty stems almost entirely from the human architecture of the firm. The firm may require different skill sets implying a release of some existing employees and acquisition of new employees. The change entails different organizational processes implying new networks and new behavioral repertoires of employees. The new skills and new behaviors theoretically must be driven by new administrative, (i.e., HR) systems. (Wright \& Snell, 1998).

This implies the centrality of HR issues to the understanding and development of dynamic capabilities. This centrality is well articulated by Teece et al. (1997) who note "Indeed if control over scarce resources is the source of economic profits, then it follows that such issues as skill acquisition, the management of knowledge and know how and learning become fundamental strategic issues. It is in this second dimension, encompassing skill acquisition, learning and accumulation of organizational and intangible or invisible assets that we believe lies the greatest potential for contributions to strategy." (pp. 514-515):

\section{Knowledge-based theories of the Firm}

Unarguably, significant attention in the strategy literature within the RBV paradigm has focused on knowledge. Efforts to understand how firms generate, leverage, transfer, integrate and protect knowledge has moved to the forefront of the field (Hansen, 1999; Hedlund, 1994; Nonaka, 1991; Sveiby, 1997; Szulanski, 1996). In fact, Grant (1996) argues for a knowledgebased theory of the firm, positing that firms exist because they better integrate and apply 
specialized knowledge than do markets. Liebeskind (1996) similarly believes in a knowledgebased theory of the firm, suggesting that firms exist because they can better protect knowledge from expropriation and imitation than can markets.

Interestingly, knowledge-centered strategy research inevitably confronts a number of HR issues. Knowledge management requires that firms define knowledge, identify existing knowledge bases, and provide mechanisms to promote the creation, protection and transfer of knowledge (Argote \& Ingram, 2000; Henderson \& Cockburn, 1994; Leibeskind, 1996). While information systems provide a technological repository of knowledge, increasingly firms recognize that the key to successful knowledge management requires attending to the social and cultural systems of the organization (The Conference Board, 2000).

Knowledge has long been a topic within the HR literature, whether the focus was on testing applicants for job-related knowledge (Hattrup \& Schmitt, 1990), training employees to build their job-related knowledge (Gephart, Marsick, Van Buren, \& Spiro, 1996), developing participation and communication systems to transfer knowledge (Cooke, 1994), or providing incentives for individuals to apply their knowledge (Gerhart, Milkovich, \& Murray, 1992). The major distinctions between the strategy and HR literatures with regard to knowledge has to do with the focus of the knowledge and its level. While the HR literature has focused on job related knowledge, the strategy literature has focused on more market-relevant knowledge, such as knowledge regarding customers, competitors, or knowledge relevant to the creation of new products (Grant, 1996; Leibeskind, 1996).

In addition, while HR literature tends to treat knowledge as an individual phenomenon, the strategy and organizational literatures view it more broadly as organizationally shared, accessible, and transferable (cf., Argyris \& Schon, 1978; Brown \& Duguid, 1991; Snell, Stueber, \& Lepak, in press). Knowledge can be viewed as something that characterizes individuals (i.e., human capital), but it can also be shared within groups or networks (i.e., social capital) or institutionalized within organization processes and databases (organizational capital). 
These distinctions represent something of a departure for HR researchers. However, the processes of creation, transfer, and exploitation of knowledge provide common ground across the two fields, again highlighting their potential convergence within the RBV paradigm. Although theorists such as Argyris and Schon (1978) argue that all learning begins at the individual level, it is conditioned by the social context and routines within organizations (Nonaka \& Takeuchi, 1995). Coleman (1988), for example, noted that social capital has an important influence on the creation of human capital. What seems clear is that these different "knowledge repositories" complement and influence one another in defining an organization's capabilities (Youndt \& Snell, 2001).

But there are substantial differences between HR systems that support individual learning and those that support organizational learning. Leonard-Barton (1992), for example, noted that organizational learning and innovation were built on four inter-related processes and their related values: (1) owning/solving problems (egalitarianism), (2) integrating internal knowledge (shared knowledge), (3) continuous experimentation (positive risk), and (4) integrating external knowledge (openness to outside). Each of these processes and values works systemically with the others to inculcate organizational learning and innovation. Each process/value combination is in turn supported by different administrative (HR) systems that incorporate elements of staffing, job design, training, career management, rewards, and appraisal. Again, the concept of knowledge brings together the fields of strategy and HR. But a good deal more work needs to be done to integrate these research streams. Strategy theory and research provides the basis for understanding the value of knowledge to the firm and highlights the need to manage it. The HR field has lacked such a perspective, but has provided more theory and research regarding how knowledge is generated, retained, and transferred among individuals comprising the firm. 


\section{Integrating Strategy and SHRM within the RBV}

We have discussed the concepts of core competencies, dynamic capabilities, and knowledge as bridge constructs connecting the fields of strategy and SHRM. We proposed that both fields could benefit greatly from sharing respective areas of expertise. In fact, at the risk of oversimplification, the strategy literature has generated significant amounts of knowledge regarding who (i.e., employees/executives or groups of employees/executives) provides sources of competitive advantage and why. However, absent from that literature is specific techniques for attracting, developing, motivating, maintaining, or retaining these people. SHRM, on the other hand has generated knowledge regarding the attraction, development, motivation, maintenance, and retention of people. However, it has not been particularly successful yet at identifying who the focus of these systems should be on and why.

The strategy literature has also highlighted the importance of the stock and flow of knowledge for competitive advantage. However, it has not explored in great detail the role that individuals as well as their interactions with others contribute to this. Conversely SHRM has missed much of the organizational view of knowledge, but can provide significant guidance regarding the role that individuals play.

This state of affairs calls for greater integration between these two fields. Figure 2 illustrates this potential integration. Overall, the figure depicts people management systems at the left, core competencies at the right, intellectual capital and knowledge management as the bridge concepts between the two, and dynamic capability as a renewal component that ties all four concepts over time. 
Figure 2

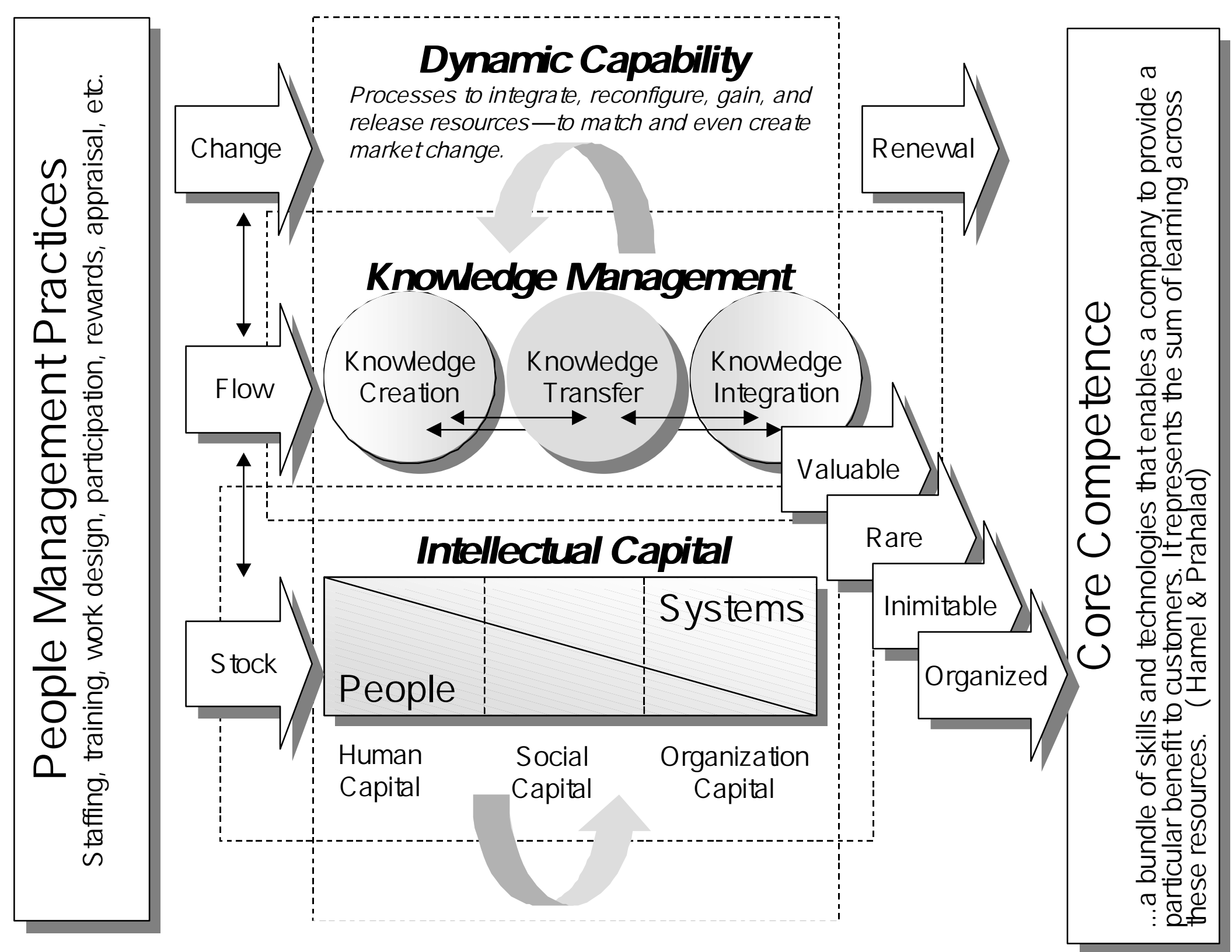


Note that the basic constructs laid out in Figure 1 still appear in this expanded model, yet with a much more detailed set of variables. At the right hand side of the model we place the people management systems construct. This placement does not imply that all competitive advantage begins with people management systems, but rather, that this represents the focus of the HR field. We suggest that these people management systems create value to the extent that they impact the stock, flow, and change of intellectual capital/knowledge that form the basis of core competencies.

Rather than simply focusing on the concepts of "skills" and "behavior" we propose a more detailed analysis with regard to the stock and flow of knowledge. To this end we suggest that the "skill" concept might be expanded to consider the stock of intellectual capital in the firm, embedded in both people and systems. This stock of human capital consists of human (the knowledge skills, and abilities of people), social (the valuable relationships among people), and organizational (the processes and routines within the firm). It broadens the traditional HR focus beyond simply the people to explore the larger processes and systems that exist within the firm.

The "behavior" concept within the SHRM literature can similarly be reconceptualized as the flow of knowledge within the firm through its creation, transfer, and integration. This "knowledge management" behavior becomes increasingly important as information and knowledge play a greater role in firm competitive advantage. It is through the flow of knowledge that firms increase or maintain the stock of intellectual capital.

At the right hand side of the model we place the core competence, one of the major foci of the strategy literature. We propose that this core competence arises from the combination of the firms stock of knowledge (human, social, and organizational capital embedded in both people and systems) and the flow of this knowledge though creation, transfer, and integration in a way that is valuable, rare, inimitable, and organized. This provides a framework for more specifically exploring the human component to core competencies, and provides a basis for 
exploring the linkage between people management systems and core competencies through the management of a firm's stock and flow of knowledge.

Finally, the dynamic capability construct illustrates the interdependent interplay between the workforce and the core competence as it changes overtime. It represents the renewal process that organizations must undergo in order to remain competitive. Dynamic capability requires changing competencies on the part of both the organization and the people who comprise it. It is facilitated by people management systems that promote the change of both the stock and flow of knowledge within the firm that enable a firm to constantly renew its core competencies.

This model by no means serves as a well-developed theoretical framework, but rather simply seeks to point to the areas for collaboration between strategy and SHRM researchers. These two fields share common interests in issues and yet bring complementary skills, knowledge, and perspectives to these issues. The RBV highlights these common interests and provides a framework for developing collaborative effort. 


\section{Conclusion}

The RBV has significantly and independently influenced the fields of strategy and SHRM. More importantly, however, it has provided a theoretical bridge between these two fields. By turning attention toward the internal resources, capabilities and competencies of the firm such as knowledge, learning, and dynamic capabilities (Hoskisson et al., 1999), it has brought strategy researchers to inescapably face a number of issues with regard to the management of people (Barney, 1996). We would guess that few strategy researchers are well versed in the existing research base regarding the effectiveness of various specific HR tools and techniques for managing people, and thus addressing these issues with necessary specificity.

This internal focus also has provided the traditionally atheoretical field of SHRM with a theoretical foundation from which it can begin exploring the strategic role that people and HR functions can play in organizations (Wright \& McMahan, 1992). In addition to the lack of theory, this literature has also displayed little, or at least overly simplistic views of strategy, thus limiting its ability to contribute to the strategy literature (Chadwick \& Cappelli, 1998). The RBV provides the framework from which HR researchers and practitioners can better understand the challenges of strategy, and thus be better able to play a positive role in the strategic management of firms.

We propose that both fields will benefit from greater levels of interaction in the future. This interaction should be deeper than simply reading each other's literature, but rather organizing conferences aimed at promoting face-to-face discussions of the common issues and challenges. In fact, we believe that future interdisciplinary research studies conducted jointly by strategy and SHRM researchers would exploit the unique knowledge and expertise of both fields, and synergistically contribute to the generation of new knowledge regarding the roles that people play in organizational competitive advantage. 


\section{References}

Argote, L., \& Ingram, P. (2000). Knowledge transfer: A basis for competitive advantage in firms. Organizational Behavior and Human Decision Processes, 82 (1), 150-169.

Argyris, C. \& Schon, D .A. (1978). Organizational learning: A theory of action perspective. Reading, MA: Addision-Wesley.

Arthur, J. B. (1994). Effects of Human Resource Systems on Manufacturing Performance and Turnover. Academy of Management Journal, 37(3), 670-687

Baron, J.N., Davis-Blake, A. \& Bielby, W.T. (1986). The structure of opportunity: How promotion ladders vary within and among organizations. Administrative Science Quarterly, 31, 248-273.

Barney, J. (1991). Firm Resources and Sustained Competitive Advantage. Journal of Managementl 17 (1), 99-120. 469.

Barney J. (1996). The resource-based theory of the firm. Organizational Science, 7 ,

Barney, J. (2001). Is the resource-based view a useful perspective for strategic management research? Yes. Academy of Management Review, 26, 41-56.

Becker, B. E., \& Huselid, M. A. (1998). High performance work systems and firm performance: A synthesis of research and managerial applications. Research in Personnel and Human Resources Management, 16, 53-101.

Brown, J.S. \& Duguid, P. (1991). Organizational learning and communities-of-practice: Toward a unified view of working, learning, and innovation. Organizational Science, 2: 40-57.

Boxall, P. F. (1996). The Strategic HRM Debate and the Resource-based View of the Firm. Human Resource Management Journal, 6(3), 59-75.

Boxall, P. F. (1998). Human resource strategy and industry-based competition: A conceptual framework and agenda for theoretical development. In P.M. Wright, L.D. Dyer, J.W. Boudreau, \& G. T. Milkovich (Eds.) Research in Personnel and Human Resources Management (Supplement 4, pp. 1-29). Madison, WI: IRRA.

Boxall, P. F., \& Steeneveld, M. (1999). Human resource strategy and competitive advantage: A longitudinal study of engineering consultancies. Journal of Management Studies, $\underline{36}(4), 443-463$.

Cappelli, P., \& Singh, H. (1992). Integrating Strategic Human Resources and Strategic Management. In D. Lewin, O. S. Mitchell, \& P. D. Sherer (Eds.), Research Frontiers in Industrial Relations and Human Resources (pp. 165-192). Madison, WI: IRRA.

Chadwick, C., \& Cappelli, P. (1998). Alternatives to Generic Strategy Typologies in Strategic Human Resource Management. In P. M. Wright, L. D. Dyer, J. W. Boudreau, \& G. T. Milkovich (Eds.), Research in Personnel and Human Resources Management (Supplement 4, pp. 1-29). Greenwich, CT: JAI Press, Inc. 
Coleman, J. S. (1988). Social capital in the creation of human capital. American Journal of Sociology, 94, s95-s120.

Conference Board. (2000). Beyond Knowledge Management: New Ways to Work. Research Report 1262-00RR.

Cooke, W. (1994). Employee participation programs, group-based incentives, and Company performance: A union-nonunion comparison. Industrial and Labor Relations Review, 47, 594-609.

Conner, K.R. and C.K. Prahalad. (1996). A Resource-Based Theory of the Firm: Knowledge Versus Opportunism. Organization Science, 7, 477-501.

Devanna, M. A., Fombrun, C. J., \& Tichy, N. M. (1984). Chapter 3: A Framework for Strategic Human Resource Management, Strategic Human Resource Management (pp. 33-51). New York: Wiley.

Dierickx, I. And K. Cool, (1989). Asset Stock Accumulation and Sustainability of Competitive Advantage. Management Science, 35, 1504-1511.

Drucker, P. (1954). The practice of management. New York: Harper.

Edvinsson, L. \& Malone, M. (1997). Intellectual capital. Cambridge, MA: Harvard Business School Press.

Eisenhardt, K. M., \& Martin, J. A. (2000). Dynamic capabilities: What are they? Strategic Management Journal, 21:1105-1121.

Fiol, C. M., \& Lyles, M. A. (1985). Organizational learning. Academy of Management Review, 10: 803-813.

Finkelstein, S., \& Hambrick, D. (1996). Strategic leadership: top executives and their effects on organizations. Minneapolis/St. Paul: West Pub. Co.

Fisher, S. R., \& White, M. A., (2000). Downsizing in a learning organization: Are there hidden costs? Academy of Management Review, 25 (1), 244-251.

Gardner, T. M., Wright, P. M., \& Gerhart, B., (2000). The HR-Firm performance relationship: Can it be in the mind $f$ the beholder? Working Paper, Center for Advanced Human Resource Studies, Cornell University.

Gephart, M. Marsick, V., Van Buren, M., \& Spiro, M., (1996). Learning Organizations come alive. Training and Development, 50, 34-35.

Gerhart, B., Milkovich, G, \& Murray, B., (1992). Pay, Performance and Participation. In D. Lewin, O. Mitchell, and P. Sherer (eds.) Research Frontiers in Industrial Relations and Human Resources. Madison, WI: IRRA

Gerhart, B., Wright, P. M., McMahan, G. C., \& Snell, S.A. (2000). Measurement error in research on human resources and firm performance: How much error is there and how does it influence effect size estimates? Personnel Psychology, 53, 803-834. 
Godfrey, P.C. and Hill, C.W.L.. (1995). The Problem of Unobservables in Strategic Management Research. Strategic Management Journal, 16, 519-533.

Grant, R.M. (1996). Toward a Knowledge-Based Theory of the Firm. Strategic Management Journal, 17 (Winter Special Issue), 108-122.

Hamel, G., \& Prahalad, C. K. (Jul/Aug, 1994). Competing for the future. Harvard Business Review, 72 (4), 122-129.

Hansen, M. T. (1999). The search-transfer problem: The role of weak ties in sharing knowledge across organization sub units. Administrative Science Quarterly, 44 (March) 82-111.

Hedlund, G. (1994). A model of knowledge management and the $\mathrm{N}$-form corporation. Strategic Management Journal, 15, 73-90.

Hattrup, K. \& Schmitt, N. (1990). "Prediction of Trades Apprentices' Performance on Job Sample Criteria." Personnel Psychology, 43,453-467.

Henderson, R. \& Cockburn, I. (1994). Measuring competence? Exploring firm effects in pharmaceutical research. Strategic Management Research, 15, 63-84.

Hitt, M.A., Bierman, L., Shimizu, K., \& Kochhar, R. (2001). Direct and moderating effects of human capital on the strategy and performance in professional service firms: A resourcebased perspective. Academy of Management Journal, 44, 13-28.

Hoskisson, R. E., Hitt, M. A., Wan, W. P., Yiu, D. (1999). Theory and research in strategic management: Swings of a pendulum. Strategic Management Journal, 25 (3), 417-456.

Huselid, M. A. (1995). The Impact of Human Resource Management Practices on Turnover, Productivity, and Corporate Financial Performance. Academy of Management Journal, 38(3), 635-672.

Jackson, S. E., Schuler, R. S., \& Rivero, J. C. (1989). Organizational Characteristics as Predictors of Personnel Practices. Personnel Psychology, 42, 727-786.

King, A. W., \& Zeithaml, C. P. (2001). Competencies and firm performance: Examining the causal ambiguity paradox. Strategic Management Journal, 22, 75-99.

Koch, M. J., \& McGrath, R. G. (1996). Improving Labor Productivity: Human Resource Management Policies do Matter. Strategic Management Journal, 17, 335-354.

Lado, A. A., \& Wilson, M. C., (1994). Human Resource Systems and Sustained Competitive Advantage: A Competency-based Perspective. Academy of Management Review, 19(4), 699-727.

Leonard-Barton, D. (1992). The factory as a learning laboratory. Sloan Management Review, Fall: 23-38. Press.

Leonard-Barton, D. (1995). Wellsprings of Knowledge. Boston: Harvard Business School 
Lepak, D. P. \& Snell, S. A. (1999). The human resource architecture: Toward a theory of human capital allocation and development. Academy of Management Review, 24, 31-48.

Lepak, D. P. \& Snell, S. A. (in press). Examining the human resource architecture: The relationships among human capital, employment, and human resource configurations. Journal of Management.

Lepak, D.P. Takeuchi, R., \& Snell, S.A. (2001). An empirical examination of employment mode use and firm performance. Working paper, University of Maryland.

Liebeskind, J.P. (1996). Knowledge, Strategy, and the Theory of the Firm. Strategic Management Journal, 17 (Winter Special Issue), 93-107.

March, J., \& Simon, H. (1958). Organizations, New York: Wiley.

MacDuffie, J. P. (1995). Human Resource Bundles and Manufacturing Performance: Organizational Logic and Flexible Production Systems in the World Auto Industry. Industrial \& Labor Relations Review, 48(2), 197-221.

Matusik, S.F. \& Hill, C.W.L. (1998). The utilization of contingent work, knowledge creation, and competitive advantage. Academy of Management Review, 23, 680-697.

McMahan, G. C., Virick, M., \& Wright, P. M. (1999). Alternative Theoretical Perspective for Strategic Human Resource Management Revisited: Progress, Problems, and Prospects. In P. M. Wright, L. D. Dyer, J. W. Boudreau, \& G. T. Milkovich (Eds.), Research in Personnel and Human Resources Management (Supplement 4, pp. 99-122). Greenwich, CT: JAI Press, Inc

Miles, R. E., \& Snow, C. C. (1978). Organizational strategy, structure and process. New York: McGraw-Hill.

Miles, R. E., \& Snow, C. C. (1984). Designing Strategic Human Resources Systems. Organizational Dynamics, Summer, 36-52.

Nonaka, I. (1991). The Knowledge Creating Company. Harvard Business Review, 69 (6), 96-104.

Nonaka, I. \& Takeuchi, H. (1995). The knowledge-creating company: How Japanese companies create the dynamics of innovation. New York: Oxford Press.

Norburn, D. \& Birley, S. (1988). The top management team and corporate performance. Strategic Management Journal, 9, 225-237.

Nordhaug, O. (1993). Human Capital in Organizations: Competence, Training and Learning. Oslo/London: Scandinavian University Press/Oxford University Press.

Nordhaug, O., \& Gronhaug, K. (1994). Competences as resources in firms. The International Journal of Human Resource Management, 5 (1), 89-106

Osterman, P. (1987). Choice of employment systems in internal labor markets. Industrial Relations, 26 (1): 48-63.

Peteraf, M.A. (1993). The cornerstones of competitive advantage: A resource based view. Strategic Management Journal, 14, 179-191. 
Penrose, E. T. (1959). The theory of the growth of the firm. New York: Wiley.

Porter, M.E. (1980). Competitive Strategy. New York: Free Press, 34-46.

Prahalad, C. K., \& Hamel, G. (1990). The Core Competence of the Corporation. Harvard Business Review, May/June 79-91.

Priem, R., L., \& Butler, J. E. (2001a). Is the resource based "view" a useful perspective for strategic management research? Academy of Management Review, 26 (1), 22-40.

Priem, R., L., \& Butler, J. E. (2001b). Tautology in the resource based view and the implications of externally determined resource value: Further comments. Academy of Management Review, 26 (1), 57-66.

Richard, O. C. (2001). Racial diversity, business strategy, and firm performance: A resource-based view. Academy of Management Journal, 43 (2), 164-177.

Rumelt, R. (1984). Toward A Strategic Theory of the Firm. In R. Lamb (ed.), Competitive Strategic Management. Englewood Cliffs, NJ: Prentice-Hall, 556-570.

Snell, S. A., Shadur, M. A., \& Wright, P. M. (in press). The era of our ways. In M. A. Hitt, R.E. Freeman, and J.S. Harrison (eds.), Handbook of strategic management, Blackwell Publishing.

Snell, S.A., Stueber, D. \& Lepak, D.P. (2001). Virtual HR departments: Getting out of the middle. In Robert L. Heneman \& David B. Greenberger (Eds.), Human Resource Management in Virtual Organizations (Information Age Publishing).

Snell, S. A., Youndt, M. A., \& Wright, P. M. (1996). Establishing a framework for research in strategic human resource management: Merging resource theory and organizational learning. In G. Ferris, (ed.). Research in Personnel and Human Resources Management, Vol. 14, 61-90.

Stalk, G., Evans, P., \& Schulman, L. (1992). Competing on capabilities: The new rules of corporate strategy. Harvard Business Review, 70, 57-69.

Stewart, T. A. (May 13, 1996). Human resources bites back. Fortune, 175.

Svieby, K. E (1997). The New Organizational Wealth: Managing and Measuring Knowledge Based Assets. San Francisco: Berrett-Koehler.

Szulanski, G. (1996). Exploring internal stickiness: impediments to the transfer of best practice within the firm. Strategic Management Journal, Winter Special Issue 17, 27-43.

Teece, D.J., Pisano, G., and Shuen, A. (1997). Dynamic Capabilities and Strategic Management. Strategic Management Journal, 18 (7), 509-533.

Thomas, A. B. (1988). Does leadership make a difference in organizational performance? Administrative Science Quarterly, 33, 388-400. 
Truss, C. \& Gratton, L. (1994). Strategic human resource management: a conceptual approach. International Journal of Human Resource Management, 5, 663-686.

Tsui, A.S., Pearce, J.L., Porter, L.W., \& Tripoli, A.M. (1997). Alternative approaches to the employee-organization relationship: Does investment in employees pay off? Academy of Management Journal, 40, 1089-1121.

Walker, J. (1978). Linking human resource planning and strategic planning. Human Resource Planning, 1, 1-18.

Wernerfelt, B. (1984). A Resource-Based View of the Firm. Strategic Management Journal, 5, 171-180.

Wernerfelt, B. (1995). The resource based view of the firm: Ten years after. Strategic Management Journal, 16, 171-174.

Wright, P. M. \& Boswell, W. (in press). Desegregating HRM: A Review and Synthesis of Micro and Macro Human Resource Management Research. Journal of Management.

Wright, P. M. \& Gardner, T. M. (in press). Theoretical and empirical challenges in studying the HR practice-firm performance relationship. In D. Holman, T.D. Wall, C. Clegg, P. Sparrow, and A. Howard (eds.), The New Workplace: People Technology, and Organization, John Wiley and Sons.

Wright, P.M., Gardner, T. M., Moynihan, L. M., Park, H., Gerhart, B., \& Delery, J. (in press). Measurement Error in Research on Human Resources and Firm Performance: Additional Data and Suggestions for Future Research. Personnel Psychology.

Wright, P. M., McCormick, B., Sherman, W. S., McMahan, G. C. (1999). The role of human resources practices in petro-chemical refinery performance. The International Journal of Human Resource Management, 10, 551-571.

Wright, P. M., \& McMahan, G. C. (1992). Theoretical Perspectives for Strategic Human Resource Management. Journal of Management, 18(2), 295-320.

Wright, P. M., McMahan, G. C., \& McWilliams, A. (1994). Human Resources and Sustained Competitive Advantage: A Resource-based Perspective. International Journal of Human Resource Management, 5(2), 301-326.

Wright, P. M., Smart, D. L., \& McMahan, G. C. (1995). Matches Between Human Resources and Strategy Among NCAA Basketball Teams. Academy of Management Journal, 38(4), 1052-1074.

Wright, P. M., \& Snell, S. A. (1991). Toward an Integrative View of Strategic Human Resource Management. Human Resource Management Review, 1 (3), 203-225.

Wright, P. M., \& Snell, S. A. (1998). Toward a Unifying Framework for Exploring Fit and Flexibility in Strategic Human Resource Management. Academy of Management Review, 23(4), 756-772.

Youndt, M.A. \& Snell, S.A. (2001) Human resource management, intellectual capital, and organizational performance. Working Paper, Skidmore College. 